\title{
The synergetic development analysis on China's new energy automobile enterprises diversification strategy - BYD as an example
}

\author{
Yan Zhang \\ School of economics, Wuhan University of Technology, Wuhan, China, 430070 \\ School of foreign languages, Wuhan University of Technology, Wuhan, China, 430070 \\ zhangyanwy@whut.edu.cn
}

\begin{abstract}
KeyWords: new energy automobile enterprise; the synergetic development; diversification strategy

Abstract: In this paper, taking the automobile enterprises BYD as the research target, based on the basic theory of synergetic development, the author constructs the new energy automobile enterprise products synergetic development quantitative evaluation model, analyses the diversification strategy of automobile industry based on selected indexes vertically, and puts forward some corresponding suggestions, in order to provide the theory support for the reasonable layout of the automobile industry and making the benefit for the enterprise, and to provide theoretical basis and decision-making reference for more effective implementation of diversification strategy of new energy automobile enterprises of our country.
\end{abstract}

When mankind entered twenty-first Century, the state began to pay more and more attention to the sustainable development strategy. Especially the sustainable development of energy in the national strategic thinking to occupy an increasingly important proportion.

The car consumes a huge oil every year, and the petroleum resources is non-renewable resources. The basic idea of the sustainable development of the car energy is while the rapid economic growth of the automobile system, with the steady development of the automobile industry, the low energy consumption and the social environment protection.

Goold considers that pursuit synergy is one of the main objectives of enterprise diversification [1]. "Synergy" is a kind of relation between different things, a mutual harmony and positive matching relationship; and "collaborative development" is the dynamic relationship between mutual promotion and synchronous forward changes in the development state of things; the diversification not related to enterprise's performance ${ }^{[2]}$, trade can't influence on diversification. The correlation between the actual results of the comprehensive evaluation and the evaluation index is proportional to the correlation degree , The higher the correlation degree between the indexes, the better the main component analysis is. When the correlation between the indicators is smaller, each principal component carries the amount of information is less ${ }^{[3]}$.

So far, Professor Qiu Dong has systemically research the theoretical problem of comprehensive evaluation method of the principal component, in 1991 he analyse the basic idea of comprehensive evaluation method, basic steps and mechanism (including the characteristics, the advantages and disadvantages)of the principal component analyze and evaluate ways ${ }^{[4]}$. In the aspect of quantitative assessment of synergy effect, the paper makes quantitative assessment of the synergetic development of urban ecological environment and economy by the introduction of the 
synergetic degree model proposed by the scholar Yang Shihong ${ }^{[5]}$. Literature ${ }^{[6]}$ based on concept of synergy for the enterprise strategy, generally the analyze accord to different aspects , such as the synergy path, evaluating collaborative performance and control risk and synergy, from the two aspects of qualitative and quantitative accurately grasp the synergy concept. Literature ${ }^{[7]}$ based on the theory of synergy strategic, deem that main business of enterprises is closely related with the real estate industry enterprises, if adopt the diversification strategy can acquire synergy, then it is good for the development of enterprises main business. Rumeltrp ${ }^{[8]}$ discusses the enterprises through diversified development strategy to obtain synergy effect , seek correct synergy types and establish appropriate synergy degree and looking for high returns the synergy opportunities and other strategic question.

\section{Synergetic development calculation and evaluation criteria}

According to the content of synergy degree in two systems, generally adopt the following three steps to get development synergy degree between the two systems: (1) Calculate the synergy degree between the two systems; (2) Calculate the synergy degree between two systems; (3) Compute the degree of development synergy based on the degree of development and the degree of synergy.

Adopt synergy of the formula putted forward by Yang Shi hong ${ }^{[6]}$,the model is:

$$
f(\mathrm{x})=\sum_{i=1}^{m} a_{i} \bar{x}_{i} \quad(1) \quad \mathrm{g}(\mathrm{y})=\sum_{i=1}^{n} b_{i} \bar{y}_{i}
$$

In the formula, $f(x)$ is the benefit index of system one; $g(y)$ is the benefit index of system two; ai and bi respecttively represent the weight of evaluation index; $x i$ is used to describe the $\mathrm{i}$-th indicator in system one; yi is used to describe the $\mathrm{i}$-th indicator in system two.

To calculate the standardization, the value of xi and yi was quantified, the value is given by the following formula;

$$
\bar{x}_{i}=x_{i} / x_{i 0}
$$

$$
\bar{x}_{i}=x_{i 0} / \mathrm{x}_{i}
$$

$x_{i 0}$ is the standard value for the $\mathrm{i}$-th index, when the index bigger the better, the value of $\mathrm{x}_{i}$ based on calculation of the formula (1), when the index smaller the better, the value of xi based on calculation of the formula (2), the value of $\bar{y}_{i}$ by similar analogy.

According to the formula $\mathrm{f}(\mathrm{x})$ and $\mathrm{g}(\mathrm{y})$ can get the comprehensive evaluation index of system two and system one, $\mathrm{t}=\mathrm{a} \mathrm{f}(\mathrm{x})+\mathrm{b} \mathrm{g}(\mathrm{y})$, $\mathrm{a}$ and $\mathrm{b}$ is weight ; This paper takes $\mathrm{a}=\mathrm{b}=0.5$. Then use relevant mathematical principles and deviation to analysis, deduced the expression of synergetic development degree of system one and two is $D=\sqrt{c t}$, where $\mathrm{C}$ is the synergy degree of system one and two, 


$$
c=\left[\frac{f(\mathrm{x}) \mathrm{g}(\mathrm{x})}{\left[\frac{f(\mathrm{x})+\mathrm{g}(\mathrm{x})}{2}\right]^{2}}\right]_{, \mathrm{k} \geq 2 .(5)}^{k}
$$

After the synergetic development degree is obtained, it should be based on certain criteria to division the level and type, according to the size of the synergetic development degree make the synergy development of system one and two divided into five types, shown as table1.1:

Table 1.1. Synergetic development evaluation criteria and types of system one and two

\begin{tabular}{|l|l|l|}
\hline $\begin{array}{l}\text { Leve } \\
1\end{array}$ & $\begin{array}{l}\text { Value of synergy } \\
\text { degree }\end{array}$ & Type \\
\hline 1 & $0.8 \leq \mathrm{D}<1$ & Good synergetic development type \\
\hline 2 & $0.6 \leq \mathrm{D}<0.8$ & General synergetic development type \\
\hline 3 & $0.4 \leq \mathrm{D}<0.6$ & $\begin{array}{l}\text { Reluctantly synergetic development } \\
\text { type }\end{array}$ \\
\hline 4 & $0.2 \leq \mathrm{D}<0.4$ & General offset recession type \\
\hline 5 & $0 \leq \mathrm{D}<0.2$ & Severe recession type \\
\hline
\end{tabular}

\section{Data collection and processing}

Table 2.1. The numerical and index of the development of BYD hybrid electric vehicle

\begin{tabular}{|c|c|c|c|c|c|c|c|}
\hline $\begin{array}{l}\text { YearsIndex } \\
\text { parameter }\end{array}$ & Total sales & $\begin{array}{l}\text { Owner's } \\
\text { rights and } \\
\text { interests of } \\
\text { different years }\end{array}$ & \multicolumn{2}{|c|}{$\begin{array}{l}\text { Total assets } \\
\text { of different } \\
\text { years }\end{array}$} & \multicolumn{2}{|c|}{$\begin{array}{l}\text { Net rofit of } \\
\text { different } \\
\text { years }\end{array}$} & $\begin{array}{l}\text { Per capital net } \\
\text { income of } \\
\text { different years }\end{array}$ \\
\hline 2010 & 1599010.93 & 6890.21 & \multicolumn{2}{|c|}{5902.21} & \multicolumn{2}{|c|}{488.22} & 1.98 \\
\hline 2011 & 1782390.33 & 7769.01 & \multicolumn{2}{|c|}{6782.14} & \multicolumn{2}{|c|}{542.98} & 2.11 \\
\hline 2012 & 1940440.99 & 9783.11 & \multicolumn{2}{|c|}{7832.21} & \multicolumn{2}{|c|}{611.02} & 2.92 \\
\hline 2013 & 2160330.48 & 10933.22 & \multicolumn{2}{|c|}{8654.19} & \multicolumn{2}{|c|}{737.22} & 3.81 \\
\hline $\begin{array}{l}\text { YearsIndex } \\
\text { parameter }\end{array}$ & Sales growth rate & $\begin{array}{l}\text { Capital } \\
\text { preservation } \\
\text { appreciation rate }\end{array}$ & and & $\begin{array}{l}\text { Total as } \\
\text { growth } \mathrm{r}\end{array}$ & & $\begin{array}{l}\text { Net profit } \\
\text { growth } \\
\text { rate }\end{array}$ & $\begin{array}{l}\text { Per capita net } \\
\text { profit growth } \\
\text { rate }\end{array}$ \\
\hline 2010 & 0.1147 & 0.1276 & & 0.1491 & & 0.1107 & 0.0657 \\
\hline 2011 & 0.0886 & 0.2592 & & 0.1548 & & 0.1273 & 0.3838 \\
\hline 2012 & 0.1133 & 0.1175 & & 0.1050 & & 0.2062 & 0.3048 \\
\hline 2013 & 0.0921 & 0.9901 & & 0.1129 & & 0.2139 & 0.2294 \\
\hline
\end{tabular}


Table 2.2. The numerical and target of the development of the BYD fuel cell vehicle

\begin{tabular}{|c|c|c|c|c|c|}
\hline \multicolumn{6}{|c|}{$\begin{array}{l}\text { Table 2.2.1 The parameters required for the evaluation of the } \\
\text { development of the BYD fuel cell vehicle: (Million) }\end{array}$} \\
\hline $\begin{array}{l}\text { Years } \\
\text { Index } \\
\text { param } \\
\text { eter }\end{array}$ & Total sales & $\begin{array}{l}\text { Owner' } \\
\mathrm{s} \text { rights } \\
\text { and } \\
\text { interests } \\
\text { of } \\
\text { different } \\
\text { years }\end{array}$ & $\begin{array}{l}\text { Total } \\
\text { assets } \\
\text { of } \\
\text { differ } \\
\text { ent } \\
\text { years }\end{array}$ & $\begin{array}{l}\text { Net } \\
\text { profit } \\
\text { of } \\
\text { differe } \\
\text { nt } \\
\text { years }\end{array}$ & $\begin{array}{l}\text { Per capital } \\
\text { net income } \\
\text { of } \\
\text { different } \\
\text { years }\end{array}$ \\
\hline 2010 & 90287.47 & 478.12 & $\begin{array}{l}4829 . \\
38\end{array}$ & 397.28 & 1.89 \\
\hline 2011 & 108221.21 & 515.30 & $\begin{array}{l}5182 . \\
22\end{array}$ & 442.29 & 2.11 \\
\hline 2012 & 124051.19 & 683.26 & $\begin{array}{l}6326 . \\
19\end{array}$ & 511.17 & 2.92 \\
\hline 2013 & 150312.52 & 793.16 & $\begin{array}{l}7421 . \\
28\end{array}$ & 637.66 & 3.81 \\
\hline \multicolumn{6}{|c|}{$\begin{array}{l}\text { Table 2.2.2 BYD fuel cell vehicle development capability } \\
\text { index }\end{array}$} \\
\hline $\begin{array}{l}\text { Years } \\
\text { Index } \\
\text { param } \\
\text { eter }\end{array}$ & $\begin{array}{l}\text { Sales } \\
\text { growth rate }\end{array}$ & $\begin{array}{l}\text { Capital } \\
\text { preservat } \\
\text { ion and } \\
\text { appreciat } \\
\text { ion rate }\end{array}$ & $\begin{array}{l}\text { Total } \\
\text { assets } \\
\text { growt } \\
\text { h rate }\end{array}$ & $\begin{array}{l}\text { Net } \\
\text { profit } \\
\text { growt } \\
\text { h rate }\end{array}$ & $\begin{array}{l}\text { Per capita } \\
\text { net profit } \\
\text { growth } \\
\text { rate }\end{array}$ \\
\hline 2010 & 0.1986 & 0.0774 & $\begin{array}{l}0.072 \\
2\end{array}$ & 0.1134 & 0.1164 \\
\hline 2011 & 0.1462 & 0.3262 & $\begin{array}{l}0.220 \\
8\end{array}$ & 0.1561 & 0.3838 \\
\hline 2012 & 0.2117 & 0.1611 & $\begin{array}{l}0.173 \\
1 \\
\end{array}$ & 0.2466 & 0.3048 \\
\hline 2013 & 0.1148 & 0.2188 & $\begin{array}{l}0.116 \\
3\end{array}$ & 0.1391 & 0.1499 \\
\hline
\end{tabular}


Table 2.3. The numerical and target of the development of the BYD blade electric vehicle

\begin{tabular}{|c|c|c|c|c|c|}
\hline \multicolumn{6}{|c|}{$\begin{array}{l}\text { Table 2.3.1 The parameters required for the evaluation of the } \\
\text { development of the BYD blade electric vehicle: (Million) }\end{array}$} \\
\hline $\begin{array}{l}\text { Years\Index } \\
\text { parameter }\end{array}$ & $\begin{array}{l}\text { Total } \\
\text { sales }\end{array}$ & \begin{tabular}{l}
\multicolumn{1}{c}{ Owner's } \\
rights and \\
interests \\
of \\
different \\
years
\end{tabular} & $\begin{array}{l}\text { Total } \\
\text { assets } \\
\text { of } \\
\text { differen } \\
\text { t years }\end{array}$ & \begin{tabular}{|l} 
Net \\
profit \\
of \\
differe \\
nt \\
years
\end{tabular} & $\begin{array}{l}\text { Per capital } \\
\text { net income } \\
\text { of } \\
\text { different } \\
\text { years }\end{array}$ \\
\hline 2010 & $\begin{array}{l}70014 . \\
21\end{array}$ & 499.34 & 3998.02 & 389.37 & 0.89 \\
\hline 2011 & $\begin{array}{l}78239 . \\
33\end{array}$ & 569.32 & 4482.14 & 421.98 & 1.09 \\
\hline 2012 & $\begin{array}{l}94044 . \\
99\end{array}$ & 733.23 & 5132.21 & \begin{tabular}{|l|}
511.02 \\
\end{tabular} & 1.92 \\
\hline 2013 & $\begin{array}{l}106033 \\
.48\end{array}$ & 883.18 & 6254.19 & 637.22 & 2.35 \\
\hline \multicolumn{6}{|c|}{$\begin{array}{l}\text { Table 2.3.2 BYD blade electric vehicle development capability } \\
\text { index }\end{array}$} \\
\hline $\begin{array}{l}\text { Years Index } \\
\text { parameter }\end{array}$ & $\begin{array}{l}\text { Sales } \\
\text { growth } \\
\text { rate }\end{array}$ & $\begin{array}{l}\text { Capital } \\
\text { preservati } \\
\text { on and } \\
\text { appreciati } \\
\text { on rate }\end{array}$ & $\begin{array}{l}\text { Total } \\
\text { assets } \\
\text { growth } \\
\text { rate }\end{array}$ & $\begin{array}{l}\text { Net } \\
\text { profit } \\
\text { growth } \\
\text { rate }\end{array}$ & $\begin{array}{l}\text { Per capita } \\
\text { net profit } \\
\text { growth rate }\end{array}$ \\
\hline 2010 & 0.1175 & 0.1403 & 0.1211 & 0.0823 & 0.2247 \\
\hline 2011 & 0.2020 & 0.2882 & 0.1450 & 0.2138 & 0.7615 \\
\hline 2012 & 0.1275 & 0.2046 & 0.2186 & 0.2466 & 0.2240 \\
\hline 2013 & 0.1781 & 0.1191 & 0.1992 & 0.1392 & 0.1982 \\
\hline
\end{tabular}

\section{The vertical comparison and development suggestions for BYD new energy auto development}

This paper analyzed the three departmental systems of BYD new energy vehicles one by one, respectively analyze the synergetic development condition of the three departmental systems in vertical direction, analyze the reasons based on the annual development synergy value and the synergetic development type. But this is only the analysis of a single system, which means that ignore influence of the external and internal environment on a single system sector. In fact, synergy relations is not only exhibition synergy between BYD corporation and the external environment, the more important is the synergy between the various inside departmental systems of BYD. Therefore, in order to adjust the relevant policies timely, for the development of the external environment, only the company can do is to adapt and cater to, or prediction based on relevant information. 


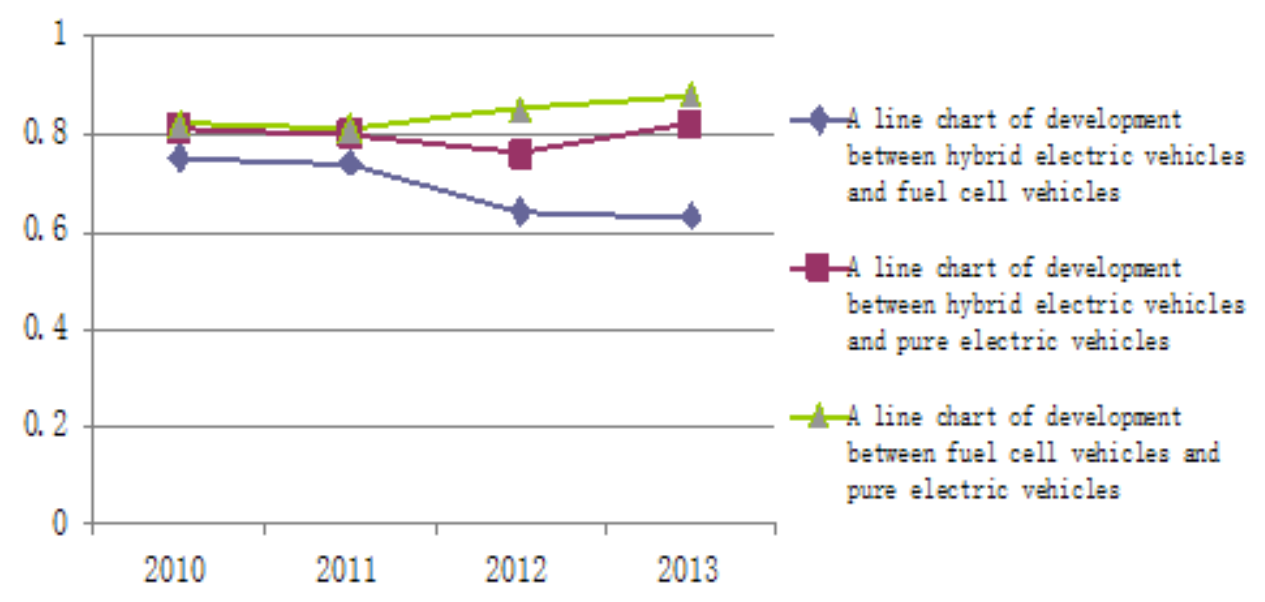

Fig.1 A line chart of development of synergetic development between the three branches system on BYD new energy vehicles

According to figure. 1 shows the synergetic development curve, from 2010 to 2011 years of synergetic development curve is basically in the fair state, that is to say, the common development between this periods of the three system is in the stable development state. From 2011 to 2012 years of hybrid cars and fuel cell vehicles and hybrid vehicles and pure electric vehicles, the synergetic development value is slightly decrease, mainly constrained by oil and other resource .Between 2012 and 2013, the synergy value increased contrast to 2012, that is to find a balance point between the two systems, the system is in a healthy development state.

Based on the above analysis, due to the influence of the external environment are required for the development of automobile, focusing on the development of new energy vehicles is the core matter of today's automotive business development, it is an inevitable choice for the automobile enterprises positive and healthy development, the new energy vehicles must occupy a considerable proportion in the automobile enterprise's financial control, that can leads the good momentum of development in automobile enterprises.

And in the new energy automotive interior systems, mainly include hybrid vehicles, fuel cell vehicles, pure electric vehicles, in terms of internal and external development environment, hybrid vehicle is still the development core of new energy automotive systems, it is the top priority, in the financial system, it impact on other systems larger, and the traditional automobiles can be traced to the same origin, both of them are closely linked, directly affect the enterprise's development. The support for fuel cell vehicles should be in the secondary status, and its development is mainly subject to technical bottleneck, but it has a strong development prospect. Then it is a pure electric car system, it is mainly restricted by limited technical and current infrastructure development environment, but with the pure electric vehicle infrastructure completed in society, the pure electric vehicle industry has a bright development prospects.

Acknowledgements: This work is supported by the National Natural Science Foundation of China, based on the quantitative relationship between energy efficiency and thermal energy, and the internal temperature distribution of power battery was constructed. Project Number: 51106115. 


\section{References:}

1. Goold M,Luchs K. Why Diversify Four Decades of Management Thinking [J].Academy of Management Executive, 1993.

2. Wei Xiaoke. Relationship research of Performance and Corporate Diversification causal past [J]. Management review, 2008 ,pp. 45-49.

3. Wang Xinhua, enterprise performance evaluation method research review [J]. Human resources, 2010 (1): 249-250.

4. Feng Ziqin.Study on Financial Synergetic Control of enterprise groups [D]. Wuhan University of Technology, 2010, pp.55-60.

5. Jie Shen, Analysis of the synergy effect of diversification strategy for enterprises [J], economy and management, 2009, pp. 49-54.

6. Li Weijie, Yan Song, Enterprise strategic synergy: theoretical overview and practice in China [J], Contemporary economic management, 2013, pp.8-15

7. Chen collection, Zeng Dan, Yang Yan, Li Chuan guo, The synergy effect of diversification strategy -- Taking the enterprise in the real estate industry as an example [J]. Enterprise systems engineering, 2012, pp.9-14.

8. RUMELT R. P. Strategy, structure and economic performance [M]. Cambridge: Harvard University, (1974) 